\title{
Peningkatan Pemahaman Hukum Masyarakat Terhadap Kebijakan Pemerintah dalam Pencegahan COVID-19 Melalui Media Poster di Desa Tombawatu Kecamatan Kapoiala Kabupaten Konawe
}

\author{
Fitriah Faisal $^{1}$, Isnayanti ${ }^{2}$, Arfa $^{3}$, Rahman Hasima ${ }^{4}$ \\ Universitas Halu Oleo, \\ Jl. H.E.A. Mokodompit Kampus Hijau Bumi Tridharma Anduonohu, Kendari 1,2,3,4 \\ Email: rahmanhasima@uho.ac.id
}

\begin{abstract}
ABSTRAK
Tujuan kegiatan pengabdian ini adalah untuk meningkatkan pemahaman hukum masyarakat terhadap kebijakan pemerintah dalam pencegahan COVID-19 melalui media poster di Desa Tombawatu Kecamatan Kapoiala Kabupaten Konawe. Tahap pelaksanaan meliputi: (1) sosialisasi terkait kebijakan pemerintah dalam pencegahan COVID-19 yang diatur dalam Peraturan Gubernur Sulawesi Tenggara Nomor 29 Tahun 2020 tentang Pedoman Penerapan Disiplin dan Penegakan Hukum Protokol Kesehatan dalam Pencegahan dan Pengendalian COVID-19 melalui media poster, (2) Poster yang sudah dibuat dan dicetak ditempel dirumah warga desa mitra sebagai bentuk edukasi ketika nantinya kegiatan pengabdian telah selesai. Metode yang digunakan selama proses kegiatan pengabdian kepada masyarakat meliputi (a) metode ceramah untuk memberikan penjelasan secara langsung kepada masyarakatt (b) metode tanya jawab untuk menggali pengetahuan masyarakat atas materi yang diberikan. Hasil kegiatan pengabdian ini menunjukan bahwa meningkatnya pemahaman hukum masyarakat Desa Tombawatu terkait kebijakan pemerintah dalam pencegahan COVID-19, hal ini dapat dilihat dari sebelum dan sesudah kegiatan pengabdian dilakukan dengan persentase sebesar 55\% masyarakat memahami peraturan gubernur tersebut sehingga berdampak terhadap peningkatan pemahaman hukum masyarakat atas kebijakan pemerintah dalam pencegahan COVID-19.
\end{abstract}

Kata kunci: Pemahaman Hukum; COVID-19; Kebijakan; Media Poster

\section{ABSTRACT}

The purpose of this devotional activity is to improve people's legal understanding of government policy in the prevention of COVID-19 through media posters in Tombawatu Village Kapoiala District Konawe Regency. Implementation stages include: (1) socialization related to government policy in the prevention of COVID-19 stipulated in The Governor of Southeast Sulawesi Regulation No. 29 of 2020 on Guidelines for The Implementation of Discipline and Law Enforcement of Health Protocols in the Prevention and Control of COVID-19 through poster media, (2) Posters that have been made and printed stamped on the homes of partner villagers as a form of education when the devotional activities have been completed. Methods used during the process of community service activities include (a) lecture methods to provide a direct explanation to the community $(b)$ question and answer methods to explore the public's knowledge of the materials provided. The results of this devotional activity show that the increasing understanding of tombawatu village law related to government policy in the prevention of COVID-19, this can be seen from before and after the devotional activities are carried out with a percentage of $55 \%$ of the community understanding the governor's regulations thus impacting the increasing understanding of public law on government policy in the prevention of COVID19.

Keywords: Legal Understanding; COVID-19; Policy; Media Posters 


\section{PENDAHULUAN}

Semua negara saat ini mengalami pandemi COVID-19 yang berdampak besar pada seluruh sektor kehidupan manusia. World Health Organization (WHO) menetapkan COVID-19 (coronavirus disease 2019) sebagai suatu pandemic global (Aprista Ristyawati, 2020). Namun yang terjadi di Indonesia seakan suatu hal yang biasa padahal di negaranegara lain penyebaran COVID-19 sangat cepat. Pada akhirnya Presiden Indonesia Joko Widodo dalam konfrensi persnya pada awal bulan maret tahun 2020 menyatakan adanya kasus COVID-19 terjadi di Indonesia yang disebabkan oleh virus SARS-Cov-2 yang dikenal dengan virus corona.

Penyebaran virus corona ini tidak terpikirkan sebelumnya akan sampai di Indonesia yang pada akhirnya sampai sekarang masih terus mengalami peningkatan kasus COVID-19. Jumlah kasus COVID-19 yang terus meningkat selain diperlukan upaya pencegahan secara medis juga melalui suatu regulasi yang jelas oleh pemerintah pusat maupun pemerintah daerah (Telaumbanua, 2020). Pandemi COVID-19 diperkirakan akan berakhir pada bulan maret hingga April 2020. Namun berdasarkan perkembangan kasus COVID-19 perkiraaan tersebut bisa mengalami perubahan berdasarkan pada hasil perkiraan Pusat Pemodelan Matematika dan Simulasi pada Institut Teknologi Bandung (CNN, 2020). Perkiraan tersebut diatas buka untuk menakut-nakuti masyarakat namun lebih pada peningkatan kewaspadaan masyarakat serta memberikan gambaran kepada pemerintah dalam pencegahan dan pengendalian COVID-19 secara komprehensif. Upaya untuk memutus mata rantai penyebaran COVID-19 dilakukan oleh pemerintah dengan menerbitkan beberapa kebijakan atau peraturan untuk dipatuhi oleh masyarakat (Syafrida, et al, 2020).

Dalam upaya penanggulan COVID-19, pemerintah telah menerbitkan beberapa aturan atau regulasi antara lain: (i) Peraturan Pemerintah Pengganti Undang-Undang Nomor 1 Tahun 2020 tentang Kebijakan Keuangan Negara dan Stabilitas Sistem Keuangan Untuk Penanganan COVID-19 dan/atau Acaman yang membahayakan Perekonomian atau Stabilitas Sistem Keuangan yang ditetapkan pada tanggal 31 maret 2020; (ii) Peraturan Pemerintah Nomor 21 Tahun 2020 tentang Pembatasan Sosial Berskala Besar dalam Rangka Percepatan Penanganan COVID-19 (iii) Instruksi Presiden Nomor 4 Tahun 2020 tentang Refocusing Kegiatan, Relokasi Anggaran serta Pengadaan Barang dan Jasa dalam Rangka Mempercepat Penanganan COVID-19; (iv) Keputusan Presiden Nomor 11 Tahun 2020 tentang Penetapan Kedaruratan Masyarakat; (v) Keputusan Presiden Nomor 12 Tahun 2020 tentang Penetapan Bencana Non Alam Penyebaran COVID-19 sebagai Bencana Nasional; 
(vi) Keputusan Presiden Nomor 7 Tahun 2020 tentang Gugus Tugas Percepatan Penanganan COVID-19; (vii) Keputusan Presiden Nomor 9 Tahun 2020 tentang Perubahan Keputusan Presiden Nomor 7 Tahun 2020 tentang Gugus Tugas Percepatan Penanganan COVID-19; (viii) Maklumat KAPOLRI Nomor: Mak/2/III/2020 tentang Kepatuhan Terhadap Kebijakan Pemerintah Dalam Penanganan COVID-19 (Michael, 2020). Kebijakan ini lahir dalam rangka penangan dan pengendalian penyebaran COVID-19 sebagai upaya pendukung keberadaan Undang-Undang Nomor 24 Tahun 2007 tentang Penanggulangan Bencana yang menetapkan wabah penyakit sebagai salah satu bencana non-alam yang perlu dikelola potensi ancaman yang akan muncul.

Berdasarkan regulasi tersebut diatas, pada tingkat daerah kemudian menerbitkan kebijakan sebagai tindaklanjut dari peraturan yang lebih tinggi salah satunya melalui peraturan daerah atau peraturan gubernur atau peraturan walikota/bupati. Hal ini direspon dengan cepat oleh pemerintah daerah Provinsi Sulawesi Tenggara dengan menerbitkan Peraturan Gubernur Nomor 29 Tahun 2020 tentang Pedoman Disiplin dan Penegakan Hukum Protokol Kesehatan dalam Pencegahan dan Pengendalian COVID-19. Adapun ruang lingkup pengaturan dalam Pergub tersebut antara lain: (1) Pelaksanaan, (2) monitoring dan evaluasi, (3) Sanksi, (4) Sosialisasi dan partisipasi, dan (5) Pendanaan. Fokus dalam kegiatan pengabdian ini adalah terkait dengan pelaksanaan dalam hal ini kewajiban bagi orang perorangan maupun pelaku usaha dalam menerapakan protokol kesehatan serta sanksi apabila protokol kesehatan tersebut tidak diterapkan.

Berdasarkan peta persebaran kasus COVID-19 di Sulawesi Tenggara yang terus mengalami peningkatan jumlah kasus salah satunya di daerah Kabupaten Konawe. Jumlah kaasus positif COVID-19 di Kabupaten Konawe pertanggal 12 November 2020 sebanyak 309 orang, kasus positif yang masih diisolasi berjumlah 120 orang dan kontak erat terhadap pasien positif berjumlah 152 orang (Dinas Kesehatan Provinsi Sulawesi Tenggara, 2020)

Kasus COVID-19 di Kabupaten Konawe khususnya di Desa Tombawatu Kecamata Kapoiala masih tergolong di zona merah sehingga diperlukan upaya untuk membantu pemerintah daerah dalam rangka pencegahan dan pengendalian COVID-19 melalui kegiatan pengabdian kepada masyarakat untuk mengurangi dan menekan penyebaran COVID-19 di Kabupaten Konawe khususnya di Desa Tombawatu dengan kegiatan program kemitraan masyarakat rangka peningkatan pemahaman hukum masyarakat terkait dengan kebijakan pemeritah dalam pencegahan COVID-19 dalam Peraturan Gubernur Sulawesi Tenggara Nomor 29 Tahun 2020 tentang Pedoman Disiplin dan Penegakan Hukum Protokol Kesehatan dalam Pencegahan dan Pengendalian COVID-19. 
Berdasarkan uraian diatas, terdapat beberapa masalah yang dihadapi oleh masyarakat Desa Tombawatu dalam menerapkan Peraturan Gubernur Nomor 29 Tahun 2020 tentang Pedoman Disiplin dan Penegakan Hukum Protokol Kesehatan dalam Pencegahan dan Pengendalian COVID-19 antara lain sebagai berikut: (a) pemahaman dan pengetahuan masyarakat mengenai kebijakan pemerintah tentang pencegahan COVID-19 masih kurang, (b) kemampuan dalam penerapan ketentuan Pergub tersebut masih rendah, (c) kesadaran hukum masyarakat dalam mengimplementasikan Pergub tersebut masih kurang.

\section{METODE}

Metode yang digunakan dalam kegiatan ini meliputi: (a) metode ceramah yaitu memberikan materi secara langsung terkait ketentuan dalam Peraturan Gubernur Nomor 29 Tahun 2020 tentang Pedoman Penerapan Disiplin dan Penegakan Hukum Protokol Kesehatan dalam Pencegahan dan Pengendalian COVID-19, (b) metode tanya jawab yaitu menerima penjelasan atau pertanyaan dari masyarakat, hal ini memungkinkan semua masyarakat dapat menggali pengetahuan sebanyak-banyaknya tentang materi sosialisasi dan juga sebagai bahan untuk menerapkan dalam lingkungan keluarga.

\section{HASIL, PEMBAHASAN DAN DAMPAK}

Kegiatan pengabdian dilaksanakan pada hari Sabtu tanggal 31 Oktober 2020 pukul 09.00 - 12.30 wita di Kantor Desa Tombawatu Kecamatan Kapoiala Kabupaten Konawe dan peserta yang hadir dalam kegiatan tersebut berjumlah 20 orang. Pada pelaksanaan kegiatan pengabdian, tim pengabdian kepada masyarakat memberikan materi tentang ketentuan yang diatur dalam Peraturan Gubernur Sulawesi Tenggara Nomor 29 Tahun 2020 tentang Pedoman Disiplin dan Penegakan Hukum Protokol Kesehatan dalam pencegahan dan Pengendalian COVID-19. Kemudian tim pengabdian kepada masyarakat memuat materi muatan Pergub tersebut dalam bentuk poster seperti pada gambar 1. 


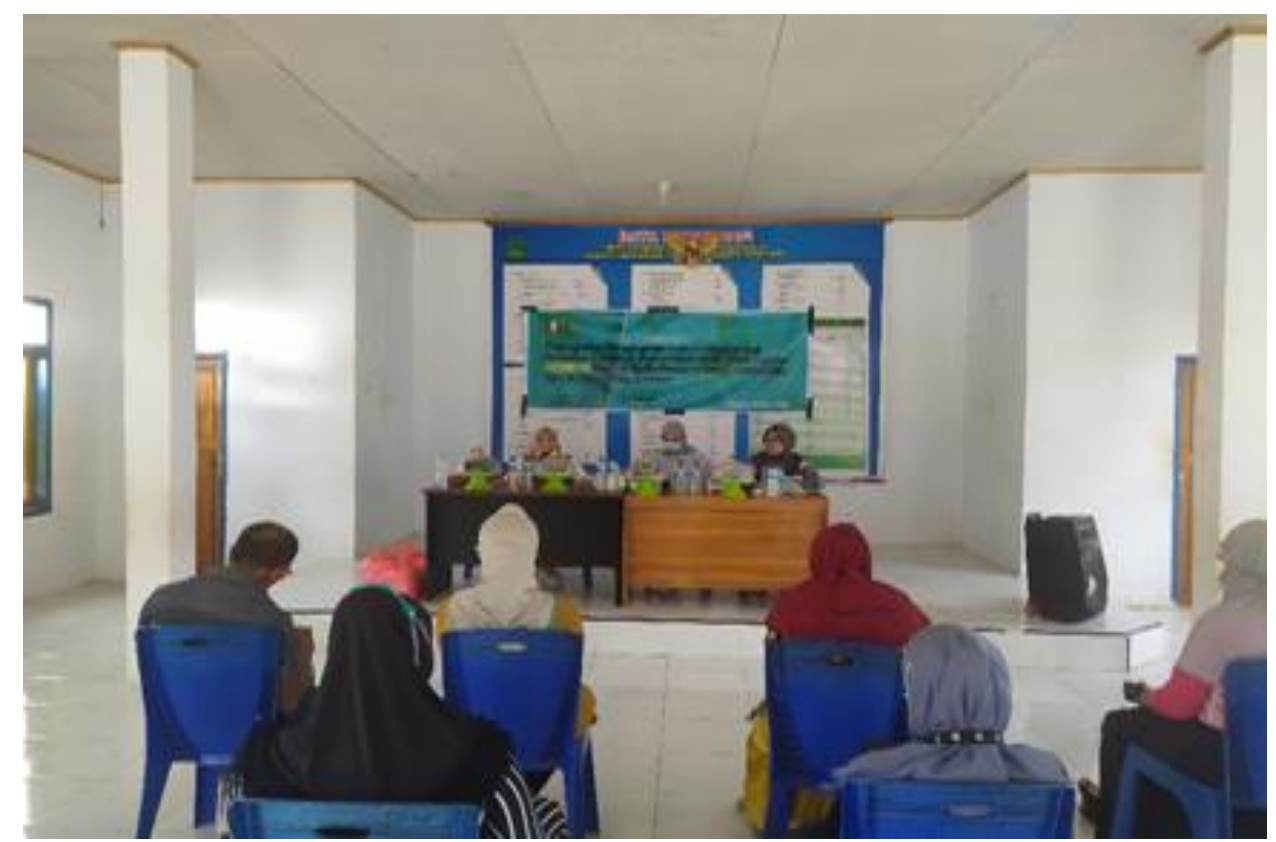

Gambar 1. Penyampaian Materi Oleh Tim Pengabdian Kepada Masyarakat

Selain itu, antusias peserta dalam mengikuti kegiatan pengabdian ini juga ditandai dengan adanya respon positif dari masyarakat dengan mengajukan pertanyaan terkait dengan ketentuan yang diatur dalam Pergub tersebut. Salah satunya pertanyaan yang diberikan oleh Kepala Desa Tombawatu. Setelah mengikuti kegiatan pengabdian ini peserta mampu memahami dan mengetahui ketentuan dalam Pergub tersebut. Hal ini tampak pada gambar 2.

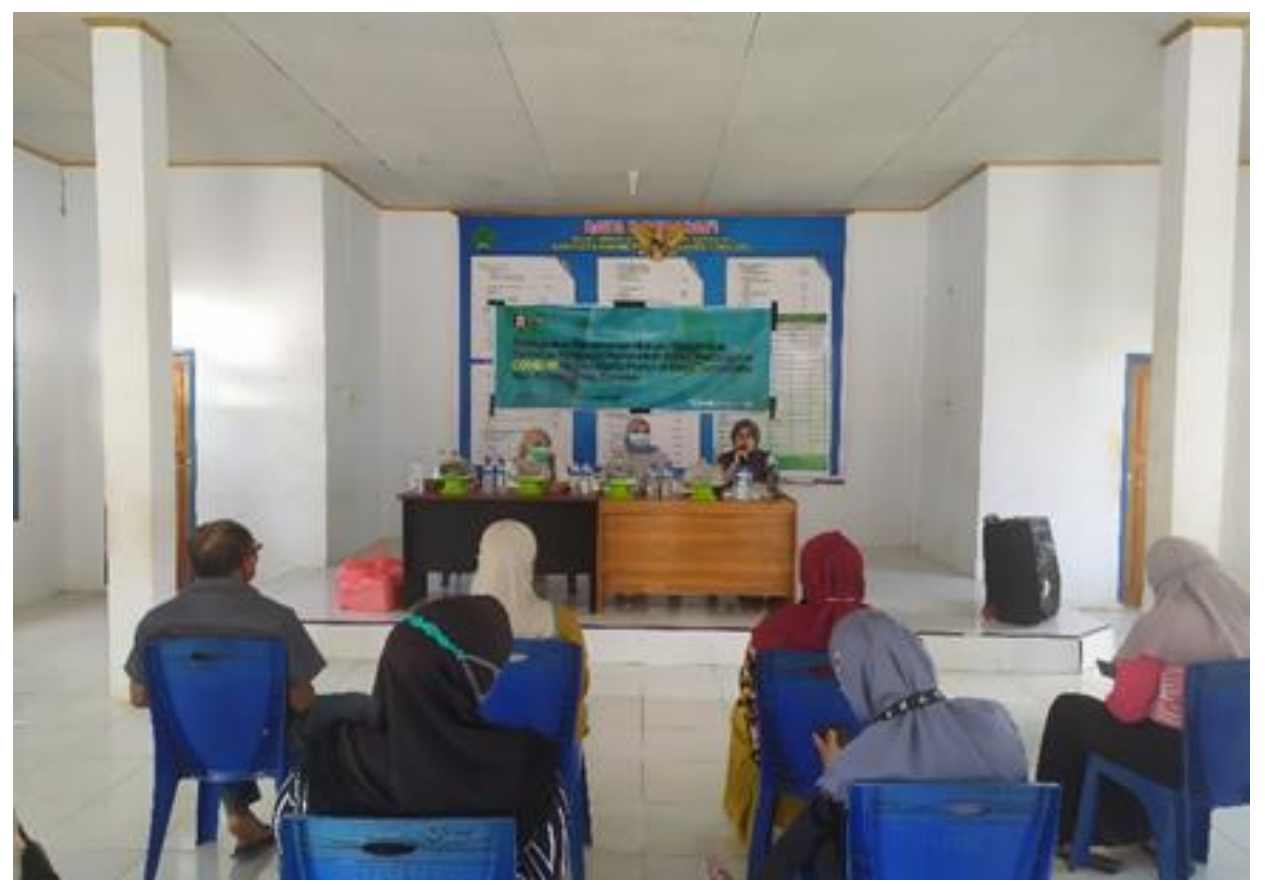

Gambar 2. Salah Satu Peserta Mengajukan Pertanyaan 
Ketentuan yang diatur dalam Perbu tersebut oleh tim pengabdian dibuat dalam bentuk poster dan diberikan kepada masyarakat dengan cara mendatangi rumah-rumah warga sebagai bentuk edukasi kepada masyarakat sehingga menarik minat warga serta dapat menjadi media informasi bagi warga ketika kegiatan pengabdian ini berakhir. Seperti pada gambar 3.

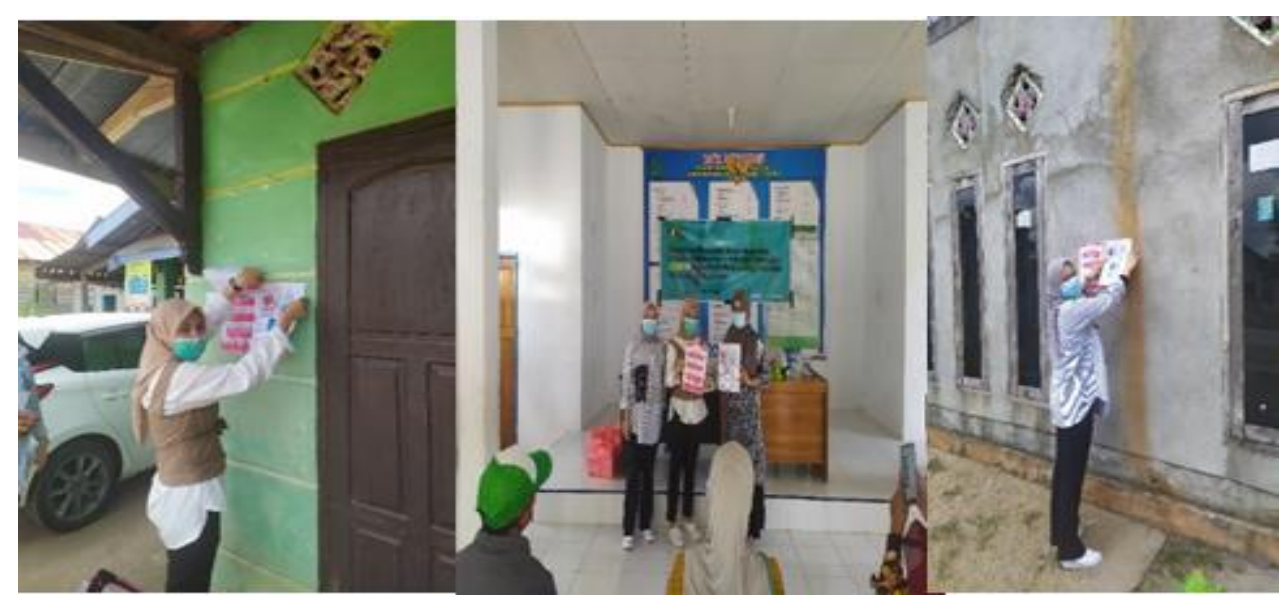

Gambar 3. Ketentuan dalam Pergub Sultra dikemas dalam bentuk Poster dan Ditempel dirumah warga

Hasil kegiatan pengabdian yang dilakukan dari tahap penyampaian materi sampai dengan pembagian poster dan ditempel dirumah warga Desa Tombawatu menggambarkan pengetahuan dan pemahaman masyarakat sebelum dan setelah mengikuti kegiatan pengabdian ini yang terkait dengan ketentuan dalam Pergub tersebut. Hasil kegiatan tersaji dalam tabel 1.

Tabel 1. Hasil Evaluasi Kegiatan

\begin{tabular}{clcc}
\hline No. & \multicolumn{1}{c}{ Aspek } & $\begin{array}{c}\text { Sebelum } \\
\text { Kegiatan }\end{array}$ & $\begin{array}{c}\text { Setelah } \\
\text { Kegiatan }\end{array}$ \\
\hline 1 & $\begin{array}{l}\text { Pemahaman masyarakat atas ketentuan yang } \\
\text { diatur dalam Peraturan Gubernur Sulawesi }\end{array}$ & $30 \%$ & $85 \%$ \\
$\begin{array}{l}\text { Tenggara Nomor 29 Tahun 2020 } \\
\text { Ketentuan Perbug Sulawesi Tenggara Nomor 29 } \\
\text { Tahun 2020 dalam bentuk Poster dapat menarik } \\
\text { minat masyarakat }\end{array}$ & $30 \%$ & $85 \%$ \\
\hline
\end{tabular}

Bersadarkan tabel 1 menunjukan bawah pemahaman masyarakat sebelum dan setelah dilaksanakan kegiatan sosialisasi terkait ketentuan Perbug tersebut terjadi peningkatan sebesar 55\% artinya bahwa kegiatan pengabdian yang dilaksanakan berdampak terhadap pengetahuan dan pemahaman hukum masyarakat Desa Tombawatu terkait ketentuan dalam Pergub tersebut dalam rangka pencegahan dan pengendalian COVID-19.

Selain itu, ketentuan Peraturan Gubernur Sulawesi Tenggara Nomor 25 Tahun 2020 tentang Pedoman Penerapan Disiplin dan Penegakan Hukum Protokol Kesehatan Dalam 
Pencegahan dan Pengendalian COVID-19 yang dibuat dalam bentuk Poster dapat menarik minat masyarakat, hal ini ditunjukan dengan adanya peningkatan sebesar 55\% yang berarti bahwa kegiatan yang dilaksanakan juga berdampak terhadap pemahaman masyarakat terkait kebijakan pemerintah dalam pencegahan dan pengendalian COVID-19.

Peningkatan pemahaman tersebut terjadi karena menggunakan metode dan media yang tepat seperti ceramah, diskusi dan menggunakan media poster sehingga membantu masyarakat untuk lebih mudah memahami materi yang diberikan pada saat pelaksanaan kegiatan pengabdian terkait dengan ketentuan yang diatur dalam Pergub tersebut dalam rangka pencegahan dan pengendalian COVID-19.

Secara umum hukum dipahami sabgai aturan yang dibuat oleh penguasa untuk mengatur masyarakat dan seluruh kegiatan demi terciptanya ketertiban umum dan keadilan. Hukum ditegakan oleh aparat penegak hukum dengan melakukan upaya-upaya penataan penindakan atau paksaan (Purwaka, 2015). Memperhatikan hal tersebut maka masyarakat Desa Tombawatu harus lebih patuh terhadap aturan yang telah ditetapkan karena telah dilengkapi dengan adanya media informasi melalui media poster yang telah dibagikan dan dipasang di rumah-rumah warga.

\section{SIMPULAN}

Hasil yang dicapai dalam kegiatan pengabdian ini adalah meningkatnya pemahaman hukum masyarakat Desa Tombawatu terkait dengan ketentuan dalam Peraturan Gubernur Sulawesi Tenggara Nomor 29 Tahun 2020 tentang Pedoman Disiplin dan Penegakan Hukum Protokol Kesehatan dalam Pencegahan dan Pengendalian COVID-19. Hal ini ditujukkan dengan perbedaan pemahaman masyarakat sebelum dan sesudah dilaksanakan kegiatan pengabdian kepada masyarakat yaitu sebesar 55\% sehingga berdampak terhadap pemahaman hukum masyarakat terhadap ketentuan yang diatur dalam pergub tersebut dalam rangka pencegahan dan pengendalian COVID-19.

\section{UCAPAN TERIMAKASIH}

Ucapan terima kasih kepada Lembaga Penelitian dan Pengabdian Kepada Masyarakat (LPPM) Universitas Halu Oleo atas kepercayaan yang diberikan kepada kami untuk melaksanakan kegiatan pengabdian ini melalui bantuan dana pengabdian. Kemudian Dekan Fakultas Hukum Universitas Halu Oleo yang telah memberikan persetujuan dan petunjuk dalam pelaksanaan pengabdian ini serta secara khusus kami ucapkan terima kasih atas kesediaannya dan partisipasi masyarakat dan Pemerintah Desa Tombawatu dalam kegiatan 
pengabdian ini dan telah memberikan persetujuan terhadap wilayah untuk dijadikan tempat pelaksanaan kegiatan pengabdian kepada masyarakat.

\section{DAFTAR PUSTAKA}

Aprista Ristiawati. (2020). Efektifitas Kebijakan Pembatasan Sosial Berskala Besar dalam Masa Pandemi Corona Virus 2019 oleh Pemerintah Sesuai Amanat UUD NRI Tahun 1945. Administrative Law \& Governance Journal, 3 (2), 240-249

CNN, ITB: Puncak Corona RI Akhir Maret, Berakhir Tengah April 2020, 2020, diakses dari https://www.cnnindonesia.com/teknologi/20200319142837-199-484974/itb-puncakcorona-ri-akhir-maret-berakhir-tengah-april-2020 pada 25 Maret 2020

Dalinama Telaumbanua. (2020). Tinjauan Yuridis Penetapan Kedaruratan Kesehatan Masyarakat Akibat COVID-19. Jurnal Education and development, 8 (2), 30-36

Kementerian Kesehatan RI, Direktorat Jenderal Pencegahan dan Pengendalian Penyakit (P2P) Tahun 2020. Pedoman Kesiapsiagaan Menghadapi Coronavirus Disease (Covid-19)

Syafrida dan Ralang Hartati. (2020). Bersama Melawan Virus Covid-19 di Indonesia. Salam: Jurnal Sosial dan Budaya Syar-i, 7 (6), 495-508, DOI: 10.15408/sjsbs.v7i6.15325

Tommy Hendra Purwaka. (2015). Beberapa Pendekatan Untuk Memahami Hukum. Jurnal Hukum dan Peradilan, 4 (3), 519-536

Tomy Michael. (2020). Hukum Tata Negara Darurat Corona di Indonesia. Jurnal Mimbar Keadilan, 13 (2), 163-172

World Health Organization, WHO Director-General's opening remarks at the media briefing on Covid-19-11 March 2020, diakses dari https://www.who.int/dg/speeches/detail/who-director-general-s-opening-remarks-atthe-media-briefing-on-COVID-19 - 11-march-2020 pada 16 Maret 2020 